\title{
CITES and the livelihoods of the poor
}

\author{
B A R N E Y D I C K S O N
}

\begin{abstract}
In the recent past many international conservation institutions, including the Convention on International Trade in Endangered Species of Wild Fauna and Flora (CITES), have addressed the relationship between their work and poverty. The empirical evidence suggests that while it is not the case that large numbers of the global poor are engaged in trading CITES-listed species, in particular cases the trade in such species may be important to the livelihoods of the poor at the local level. The approach of CITES to poverty issues has evolved over time. Prompted in part by their experience of the trade in Harpagophytum spp. the Parties to CITES, at the last two meetings of the Conference of the Parties, adopted decisions that accepted an obligation to take into account the impacts of CITES listings on the livelihoods of the poor and initiated a process to assist countries that wish to do this. These decisions, while respecting the primary focus of the CITES Convention on conservation, have some affinities with the 'Do no harm' approach to the livelihoods of the poor. The process will produce guidelines and rapid assessment tools. If these guidelines and tools are to be effective they will need to take account of the contextspecific nature of solutions in this area. The CITES case provides lessons for other international conservation institutions whose activities affect the livelihoods of the poor at the local level.
\end{abstract}

Keywords CITES, Harpagophytum, livelihoods, poverty, wildlife trade.

\section{Introduction}

$\mathrm{T}$ the past decade there has been a new emphasis in the international community on poverty reduction. This is exemplified by the adoption of the UN Millennium Development Goals (UN, 2008). Many international conservation institutions have attempted to align themselves with these efforts to address poverty, and the Convention on International Trade in Endangered Species of Wild Fauna \& Flora (CITES) is no exception. At the 13th and 14th Conferences of the Parties (held in October 2004 and June 2007) CITES passed decisions that accepted an obligation to take into account impacts on the livelihoods of the poor

BARney Dickson* Fauna \& Flora International, 4th Floor, Jupiter House, Station Road, Cambridge, CB1 2JD, UK. E-mail barney.dickson@unepwcmc.org

*Current address: UNEP-WCMC, 219 Huntingdon Road, Cambridge, CB3 0DL, UK.

Received 14 May 2008. Revision requested 16 June 2008.

Accepted 30 June 2008. and that undertook to launch a process to assist countries that wish to do this. These decisions represent a significant milestone within a Convention that has often prided itself on its focus on conservation. This paper describes what led up to those decisions and argues that they result from the convergence of two major concerns. I consider whether the measures will be successful and conclude by discussing the lessons of the CITES case for other international conservation institutions that are grappling with the question of how to reconcile conservation and poverty reduction. It is necessary to begin by saying something about the key features of CITES qua conservation treaty and to assess what is known about the existing impacts of CITES regulation on poverty.

\section{Key features of CITES}

CITES is an international conservation treaty with 172 Parties (at August 2007). It is designed to prevent the trade in wild species being a threat to the survival of those species. The governing body of CITES, the Conference of the Parties (COP), meets every 2-3 years and is served by a Secretariat based in Geneva. Several other bodies have been created to carry out the business of the treaty, including the Standing Committee, which oversees the work of the Convention between COPs, and the Animals and Plants Committees, which address technical issues.

The primary tool that CITES has for addressing problems perceived to be caused by the trade in wild species is trade regulation. Trade regulations are imposed whenever the COP decides to list a species in either Appendix I or Appendix II of the Convention. Countries also have the option of placing a species subject to regulation within its jurisdiction in Appendix III. This does not require a vote by the COP. In addition to listing a species in Appendix I or II, the COP can guide the activities of the Parties in other ways. The Parties can pass recommendations, by adopting either Resolutions or Decisions. Decisions are intended to be short-term recommendations, typically covering the period before the next COP, whereas Resolutions have a longer life span (Wijnstekers, 2003).

The broad criteria for listing species on Appendices I and II are set out in the Convention. The Parties have subsequently elaborated these through a number of resolutions and the current, detailed criteria appear in Resolution Conf. 9.24 (Rev. CoP 13). The criteria focus on the trade and biological status of the species. Appendix I is for species that are threatened with extinction and that are or may be affected by trade, and Appendix II is for species that 
may not be currently threatened but may become so unless the trade is strictly regulated. A two-thirds majority of the Parties voting yes or no is required to list a species on either of these appendices. In theory, a Party's decision on how to vote should be guided by the criteria, although there can be no guarantee that a country is not influenced by other factors (Martin, 2000a).

The effect of listing a species in either Appendix I or II is to introduce automatically regulation of the trade in that species. The nature of the trade regulation is set out in the Convention text. An Appendix I listing has the effect of banning all commercial trade in that species. A listing in Appendix II introduces a degree of regulation of the trade in the species concerned. Therefore there is an automatic link between the identification of a problem (the species satisfies the criteria for a listing in Appendix I or II) and the adoption of a particular sort of solution (the imposition of the specific trade controls entailed by a listing in Appendix I or II). It is a grounding assumption of the treaty that for threatened species in trade, trade regulation of the sort laid out in the Convention is the appropriate remedy. For some critics this is one of the central weaknesses of CITES (Martin, 200ob). They argue that once a problem has been identified for a particular species there should then be consideration of what the appropriate response is in that case, rather than the automatic imposition of a pre-determined set of measures. Nevertheless, in practice the Parties have shown a willingness to circumvent this problem by tailoring specific regulatory solutions to the case at hand (Hutton \& Dickson, 2000; Dickson, 2002, 2003).

Another area where CITES has evolved is in the way it tackles issues of development and poverty reduction. At its inception CITES was focused on conservation. The treaty was drafted and negotiated during the 1960 s and early 1970 , when there was less concern with reconciling conservation and development and before the term 'sustainable development' had been coined. More recently, references to development, poverty and rural communities have made their way into documents endorsed by the Parties.

\section{What is known about the effect of CITES on livelihoods?}

Before discussing the steps that CITES has taken to address the impacts of its listing decisions on the livelihoods of the poor, it is important to consider what is known empirically about the relationship between CITES regulation and livelihoods.

A study on wildlife and poverty, commissioned by the UK Department for International Development (DFID), makes the general point that the international wildlife trade is one of the significant ways in which the poor can gain an income from wildlife (DFID, 2002). However, many wild species in trade are not listed on CITES. As is pointed out in the most significant work to date on trade regulation and livelihoods, species covered by CITES are, with some exceptions, 'frequently not widespread, abundant and/or highly used relative to many other wild species of commercial value' (Roe et al., 2002). This suggests that, from a global perspective, the trade in CITES species is not an important phenomenon in sustaining the livelihoods of large numbers of the poor. Nevertheless, the trade in some CITES species may play a significant part at the local level in the livelihoods of people involved in the trade, even if their numbers are not absolutely large. One example is provided by the thousands of rural South Africans involved in 'tapping' Aloe forex (an Appendix II listed species) to produce aloe bitters for export, with a value of approximately USD 1.2 million in 1996 (Roe et al., 2002). This trade has continued to be significant; reported exports were on average higher in 1994-2003 than they were in 1981-1994 (Knapp, 2006). A second example is the harvesting of tegu lizards Tupinambis teguixin and T. rufescens by the rural poor in Argentina for export to the USA (Roe et al., 2002). In another example from Argentina, Rabinovich (2005) describes how the managed trade in Appendix II listed blue fronted parrot Amazona aestiva has contributed to local livelihoods.

But even in those cases where local people do derive income from the trade in CITES species (and in other cases where they do not), it is not easy to arrive at firm conclusions about the causal role of CITES in ensuring (or thwarting) those contributions to livelihoods. This is symptomatic of a wider difficulty in determining the impacts of CITES regulation (Roe et al., 2002). The several attempts to assess the effect of CITES regulation on the conservation status of listed species (ERM, 1996; IUCN, 2000; Martin, 2000a), while not agreeing in every respect, have typically suggested that the results of CITES regulation are mixed, that outcomes are affected by many other factors in addition to CITES regulation itself, and that it is not yet possible to provide a systematic account of the circumstances in which CITES regulation will (or will not) be effective in conservation terms. Roe et al. (2002) note some of the other factors that can affect outcomes. These include: other regulations affecting access to resources and markets, changes in consumer demand, habitat loss, and harvest for subsistence use and domestic trade. As is suggested by MacGregor \& Bond (2004), whether CITES regulation improves the conservation status of a species is likely to depend on how these many different factors combine to influence the incentives faced by actors at the local level. Thus the nature of the outcomes will often be case specific.

Similar observations can be made about the less-studied issue of the impact of CITES regulation on local livelihoods. In general terms, such regulation may have a negative impact where it restricts the ability of local people to derive 
an income from harvesting the species and a positive impact if it helps to conserve a resource from which they can continue to derive a regular income. But many different factors, in addition to CITES regulation, will affect what those impacts are in any particular case. As well as the factors already mentioned as affecting conservation impacts, resource and land tenure, harvester organization, and cross-agency cooperation can all be important in determining whether the trade regulation contributes to poverty alleviation at the local level (Fauna \& Flora International, 2006). While it is possible to list these factors, we do not have a systematic account of the circumstances in which CITES regulation affects the livelihoods of the poor. At most, we can note some of the cases where the outcomes are positive or negative. The case of the Tanimbar corella Cacatua goffini is one where the listing in Appendix I appears to have had negative effects for both conservation and livelihoods (Jepson et al., 2001). In contrast, the managed trade of the Appendix II listed vicuna Vicugna vicugna had positive benefits for both livelihoods and conservation (Roe et al., 2002).

In summary, it is not the case that large numbers of poor people are engaged in the trade in CITES species. Nevertheless, in particular cases the trade in such species may be important to the livelihoods of the poor at the local level. Whether CITES trade regulation promotes or undermines those livelihoods may vary from case to case. These points have implications for the way in which CITES tackles poverty issues.

\section{CITES begins to address livelihoods}

There has been a growing recognition of the linkages between the livelihoods of poor people, biodiversity and conservation (Roe, 2008). The 2010 Biodiversity target, endorsed by the Convention on Biological Diversity and by the World Summit on Sustainable Development in 2002, is 'to achieve by 2010 a significant reduction of the current rate of biodiversity loss at the global, regional and national level as a contribution to poverty alleviation and to the benefit of all life on earth' (CBD Decision VI/26, emphasis added). Another sign of this increasing awareness is the statement Biodiversity: Life Insurance for our Changing World, issued in September 2005 by the heads of the secretariats of the five biodiversity-related multilateral environmental agreements. This stated 'Biodiversity can indeed help alleviate hunger and poverty, can promote human health, and be the basis for ensuring freedom and equity for all' (Zedan et al., 2005).

As conservation institutions have attempted to address poverty issues in their practice it has become clear that the relationship between conservation and biodiversity on the one hand and livelihoods, poverty and poverty reduction on the other, is complex and contested. Roe \& Elliott (2005) describe seven different empirical hypotheses in this area and Adams et al. (2004) identify four different positions in the poverty and conservation debate, each of which combines empirical claims with evaluative commitments. Of particular interest in the context of CITES is the view that conservation institutions do have an obligation with regard to poverty but it is not an obligation to make a significant contribution to global poverty reduction targets; it is held that they may not have either the capacity or the opportunity to deliver such a contribution. Rather, the obligation is to avoid harming the livelihoods of the poor who are affected by conservation activities and, where possible, should make a contribution to poverty reduction at the local level. This can be described as the 'Do no harm' position. Recommendation V.29 (Poverty and Protected Areas) from the World Parks Congress of 2003 embodies this view (IUCN, 2003), as do the recommendations from an expert workshop on conservation and poverty reduction held in Germany in 2006 (Hedden-Dunkhorst et al., 2007).

The moves to address poverty issues within CITES have been influenced by the broader debate about conservation and poverty. One of the first steps taken within CITES was in 1992, with the passing of Resolution Conf. 8.3 (Recognition of the benefits of trade in wildlife). This recognised that 'commercial trade may be beneficial to the conservation of species and ecosystems and/or to the development of local people when carried out at levels that are not detrimental to the survival of the species in question'. While this resolution notes that there may be a link between the sustainable trade in wildlife and development, it does not place any obligation on the Parties to establish or strengthen this link. Such an obligation was established, 12 years later, partly as a result of CITES engagement with the trade in Devil's claw Harpagophytum spp., a medicinal plant found in southern Africa.

The harvesters of Devil's claw are typically extremely poor and food security is often a pressing issue. They mostly live in remote, underresourced settlements in and around the Kalahari desert. The income they receive from selling the dried root slices, which are destined for export, is very small but, in the context of their extreme poverty, of some significance (Dickson, 2005). At CITES COP 11, held in 2000, there was a proposal to list Devil's claw (Harpagophytum procumbens and $H$. zeyheri) in Appendix II. However, a number of Parties and advocacy groups objected. Some of the objections focused on the question of whether there was sufficient evidence that the species was indeed so threatened as to justify the listing. But the most forceful objections came from those who claimed that the listing would have a negative impact on the livelihoods of the harvesters. The reasoning, set out in a petition, was that the listing would send 'a wrong and negative message to the market about a safe, effective and abundant herbal remedy' (Anon., undated). It was argued that this in turn 
would lead to a drop in consumer demand, resulting in a disastrous loss of income for harvesters who had few other livelihood opportunities. In the face of the opposition the proposal was withdrawn. Although, as has been noted, livelihood considerations play no part in the formal criteria for listing decisions, they were a factor in determining the Parties' views of this proposal.

Despite the withdrawal of the listing proposal, CITES did maintain a formal interest in the trade in Devil's claw, largely through the work of the Plants Committee. This work, guided by Decisions passed at COP 11 and COP 12, together with considerable interest in the trade from other institutions, stimulated research on Devil's claw (Cole, 2003; Hachfeld, 2003; Strohbach, 2003; Dickson, 2005; Raimondo et al., 2005). It also led to a proposal that emerged from the Devil's Claw Range States Working Group and was submitted by the Plants Committee to CITES COP 13 (in $\mathrm{CoP}_{13}$ Doc. 9.2.1). This called on the Secretariat to consider ways of including information about livelihood impacts in listing proposals. After some limited discussion this proposal was amended and an additional paragraph to Resolution Conf. 8.3 was agreed. This new paragraph states that the Conference of the Parties 'Recognises that implementation of CITES-listing decisions should take into account potential impacts on the livelihoods of the poor' (Resolution Conf. 8.3 (Rev. CoP13)).

This was the first formal acknowledgement within CITES that Parties should take into account the consequences of listing decisions on the livelihoods of the poor. After COP 13, some NGOs and Parties convened a workshop in Cape Town in September 2006 to consider ways of operationalizing this new paragraph. The workshop agreed on a series of recommendations (Fauna \& Flora International, 2006). The most important of these were incorporated in draft Decisions submitted jointly to COP 14 by Argentina, China, Germany and Nicaragua (CoP14 Doc. 14).

There was more discussion of the issue, both formally and informally, at COP 14 than there had been at COP 13 and there was considerable support for the draft Decisions. After some amendments two Decisions were passed by consensus. Decision 14.3 called, inter alia, on the Standing Committee to oversee a process to develop: (1) tools for voluntary use by the Parties for the rapid assessment at the national level of the positive and negative impacts of implementing CITES listing decisions on the livelihoods of the poor, in conformity with Resolution Conf. 8.3 (Rev CoP13); (2) voluntary draft guidelines for Parties to address these impacts (CITES Decision 14.3).

Decision 14.4 called on the Secretariat to seek funds for the process set out in Decision 14.3. These Decisions reinforced the commitment that had been made in Resolution Conf 8.3 ( $\left.\mathrm{Rev} \mathrm{CoP}_{13}\right)$ to take into account impacts on the livelihoods of the poor and it set out a course of action to support Parties that wished to do this. The reference to 'positive and negative impacts' shows that the Parties have focused on the direct effects of CITES measures on the livelihoods of the poor. This has some affinities with the 'Do no harm' approach, although the CITES Parties have taken a somewhat weaker stance. While there is an implicit recognition that negative impacts are undesirable, there is no commitment to avoiding them in all circumstances.

\section{A convergence of two concerns}

The agreement on the additional paragraph in Resolution Conf 8.3, and the two Decisions passed at COP 14 resulted from the convergence of two concerns. On the one hand there was the view of many Parties that CITES needed to address livelihood issues. On the other hand, there was the view that nothing should be done to call into question CITES' primary focus on conservation. The supporters of this second view included some from the first group: they accepted that CITES needed to address livelihoods but did not want to undermine the conservation objectives of the Convention. But the adherents of the second view also included some who held that any attempt to address livelihoods would inevitably compromise those objectives and should therefore be opposed.

It proved possible to satisfy most of the supporters of both views for two main reasons. Firstly, Resolution Conf. 8.3 (Rev. CoP13) makes clear that Parties should address the impacts of CITES listing decisions on the livelihoods of the poor in the course of implementing those decisions, not in determining whether those decisions are made. For almost all Parties this provides sufficient guarantee that the goal of conservation retains its primacy within the Convention. Secondly, the guidelines that will be developed are to be voluntary ones. These two features help explain the wide degree of support for the decisions made at COP 14.

\section{Will these measures work?}

The specific measures that the Parties to CITES have decided on are to develop rapid assessment tools and guidelines on how to address impacts. Because of the role Decision 14.3 accorded to the CITES Standing Committee in overseeing the process and the schedule of Standing Committee meetings, the development of the tools and guidelines will only begin in the latter part of 2008. These measures are more likely to be successful if they take account of three things. Firstly, many different factors shape how the trade in a CITES species affects the livelihoods of the poor. A significant number of these factors operate within range states and some of them, such as rights over land and wild resources, are difficult to change quickly. Secondly, some of the other factors that affect impacts are those that originate in importing states. Thirdly, much remains unknown about the causal 
relationships between different factors and particular outcomes. Even if it is known, for example, that the trade in a CITES species contributes to livelihoods at the local level, it may not be easy to identify which particular factors are causally significant in bringing that about. It may be yet more difficult to predict the impact of a particular policy change.

In the light of these features, several points can be made about the proposed guidelines and rapid assessment tools. Firstly, the guidelines should not be too prescriptive with regard to particular ways of improving impacts on livelihoods. Solutions are likely to be case specific. While the guidelines may draw on successful outcomes for illustrative purposes, a mechanistic application of a model that works in one place to a different context is unlikely to be successful. It would be useful for the guidelines to identify, at a generic level, the kinds of factors that are likely to be important, or to focus on the types of decision-making processes that lead to the development of good solutions. Secondly, the guidelines should acknowledge that developing solutions within range states will take time and may require significant policy changes. The guidelines will need to respect Party sovereignty and it may be useful to see the formulation of the guidelines as a process, that extends over time, of supporting Parties to address livelihoods. Thirdly, the guidelines will need to address what importing countries individually, and CITES as a whole, can do to implement the Convention in a way that contributes to the livelihoods of people at the local level. In this regard, the use of stricter domestic measures (Hutton, 2000), efforts to influence consumer demand, and the automatic link between a CITES listing and a particular type of trade regulation are all relevant. Fourthly, the rapid assessment tools should focus on making an assessment of whether a given package of measures does (or will, in the case of measures under development) have a beneficial impact, rather than attempting the very challenging task of assessing the causal role of CITES trade regulation alone. Finally, the rapid assessment tools should also address the question of how information about livelihood impacts can feed into evolving policy-making.

\section{Lessons for other international conservation institutions}

Does the approach adopted by CITES provide lessons for other international conservation institutions? There are different ways of reconciling conservation and poverty reduction. The appropriateness of a given approach depends in part on the existing mandate of the institution, the type of biodiversity that it is concerned with and the role that biodiversity plays in the livelihoods of the poor.

CITES is relevant for other international conservation institutions that are also focused on the conservation of threatened components of biodiversity and where those components may not play a big role in the livelihoods of large numbers of the poor but the institution does have impacts on poverty at the local level. The CITES case suggests that, for these institutions, an approach that requires that the effects at the local level should be considered, and that it is desirable to avoid negative impacts and promote positive ones, is both reasonable and can win widespread support. This approach accepts the conservation focus of these institutions but also recognizes that there are other goals of public policy and that responsibilities with regard to poverty are of particular significance to international conservation institutions.

The CITES example may also be relevant in indicating that many solutions need to be developed within range states for particular species but that support from other states and from international institutions is important. The key to success, in the CITES case as in others, may lie in how well this balance is struck between the role of the international community and the role of individual states that are developing solutions that address conservation and livelihoods.

\section{Acknowledgements}

I would like to thank two anonymous referees for their helpful comments. I am also grateful to the participants in the CITES and Livelihoods workshop in Cape Town in September 2006. I thank the Dutch Ministry of Foreign Affairs (DGIS) for their financial support in the preparation of this paper.

\section{References}

Adams, W.M., Aveling, R., Brockington, D., Dickson, B., Elliott, J., Hutton, J. et al. (2004) Biodiversity conservation and the eradication of poverty. Science, 306, 1146-1149.

Anon. (undated) Petition to Prevent the Listing of Devil's Claw (Harpagophytum spp.) on CITES Appendix II Pending Further Research on the Status of the Resource. Circulated amongst participants at CITES COP 11, Gigiri, Kenya, April 2000.

Cole, D. (2003) The Impact of Certification on the Sustainable Use of Devil's Claw (Harpagophytum procumbens) in Namibia. Report prepared for the Non-wood Forest Products Programme of the FAO, Rome, Italy.

DFID (2002) Wildlife and Poverty Study. Department for International Development, London, UK.

Dickson, B. (2002) International Conservation Treaties, Poverty and Development: The Case of CITES. Natural Resource Perspectives No. 74. Overseas Development Institute, London, UK.

Dickson, B. (2003) What is the goal of regulating wildlife trade? Is regulation a good way to achieve the goal? In The Trade in Wildlife: Regulation for Conservation (ed. S. Oldfield), pp. 23-32. Earthscan, London, UK.

Dickson, B. (2005) Devil's Claw: Livelihoods and Conservation. Draft report for Fauna \& Flora International, Cambridge, UK. 
ERM (1996) How to Improve the Effectiveness of the Convention on International Trade in Endangered Species of Wild Fauna and Flora (CITES). Environmental Resources Management, London, UK.

Fauna \& Flora International (2006) Workshop Report: CITES and Livelihoods Workshop, September 2006. Fauna \& Flora International, Cambridge, UK.

H ACHFELD, B. (2003) Ecology and Utilisation of Harpagophytum procumbens (Devil's Claw) in Southern Africa. Federal Agency for Nature Conservation, Bonn, Germany.

Hedden-Dunkhorst, B., Specht, R. \& Schmid, G. (eds) (2007) International Expert Workshop "Linking Nature Conservation and Poverty Reduction". BfN Skripten 190. BfN, Bonn, Germany.

Hutton, J.M. (2000) Who knows best? Controversy over unilateral stricter domestic measures. In Endangered Species, Threatened Convention: The Past, Present and Future of CITES (eds J. Hutton \& B. Dickson), pp. 57-66. Earthscan, London, UK.

Hutton, J.M. \& Dickson, B. (2000) Introduction. In Endangered Species, Threatened Convention: The Past, Present and Future of CITES (eds J. Hutton \& B. Dickson), pp. xv-xx. Earthscan, London, UK.

IUCN (2000) The Effectiveness of Trade Measures Contained in the Convention on International Trade in Endangered Species of Wild Fauna and Flora. UNEP Economics, Trade and Environment Unit, Geneva, Switzerland.

IUCN (2003) World Parks Congress Recommendation V.29. IUCN, Gland, Switzerland.

Jepson, P., Brickle, N. \& Chayadin, Y. (2001) The conservation status of the Tanimbar corella and blue-streaked lory on the Tanimbar Islands, Indonesia: results of a rapid contextual survey. Oryx, 35, 224-233.

Knapp, A. (2006) A Review of the Trade in Aloe forex, with a Focus on the Role of the European Union. TRAFFIC Europe, Brussels, Belgium.

MacGregor, J. \& Bond, I. (2004) Pro-poor Conservation and CITES. International Institute for Environment and Development, London, UK.

Martin, R. (200oa) When CITES works and when it does not. In Endangered Species, Threatened Convention: The Past, Present and Future of CITES (eds J. Hutton \& B. Dickson), pp. 29-37. Earthscan, London, UK.

Martin, R. (200ob) CITES and the CBD. In Endangered Species, Threatened Convention: The Past, Present and Future of CITES (eds J. Hutton \& B. Dickson), pp. 125-133. Earthscan, London, UK.
Rabinovitch, J. (2005) Parrots, precaution and Project Elé: management in the face of multiple uncertainties. In Biodiversity \& the Precautionary Principle: Risk and Uncertainty in Conservation and Sustainable Use (eds R. Cooney \& B. Dickson), pp. 173-188. Earthscan, London, UK.

Raimondo, D., Newton, D., Fell, C., Donaldson, J. \& Dickson, B. (2005) Devil's claw Harpagophytum spp. in South Africa: conservation and livelihoods issues. TRAFFIC Bulletin, 20, 98-112.

Roe, D. (2008) The origins and evolution of the conservationpoverty debate: a review of key literature, events and policy processes. Oryx, 42, 491-503.

Roe, D. \& Elliott, J. (2005) Poverty-Conservation Linkages: A Conceptual Framework. Poverty and Conservation Learning Group, London, UK.

Roe, D., Mulliken, T., Milledge, S., Mremi, J., Mosha, S. \& Grieg-Gran, M. (2002) Making a Killing or Making a Living? Wildlife Trade, Trade Controls and Rural Livelihoods. Biodiversity and Livelihood Issues No. 6. International Institute for Environment and Development, London, UK.

S тоннасн, M. (2003) National Devil's Claw Situation Analysis, Republic of Namibia, National Resource Survey. Final report prepared for the Namibian Devil's Claw Working Group, Windhoek, Namibia.

UN (2008) UN Millennium Development Goals. Http://www.un.org/ millenniumgoals/ [accessed 1 July 2008].

Wijnstekers, W. (2003) The Evolution of CITES - 7th Edition. CITES Secretariat, Châtelaine-Geneva, Switzerland.

Zedan, H., Wijnstekers, W., Hepworth, R., Bridgewater, P. \& BANDARIN, F. (2005) Biodiversity: Life Insurance for our Changing World. Http://www.cites.org/eng/news/press/2005/ 050912_statement.shtml [accessed 22 August 2007].

\section{Biographical sketch}

B ARney Dickson was until recently Head of International Policy at Fauna \& Flora International. He worked on several issues in international conservation policy, including the relationship between poverty and conservation and the international trade in wild species. He has since been appointed Acting Head of the Climate Change and Biodiversity Programme at the UNEP-World Conservation Monitoring Centre. He has been an active participant in the events described in this paper. 